\title{
Når diagnoser gjør blind
}

\author{
Diagnoser har utilsiktede virkninger. I to norske overgrepssaker ser det ut til at ofrenes diagnoser har \\ fungert som blikkavledere - overgrep og mishandling kan ha blitt oversett fordi man antok at det var \\ sykdom barna led av.
}

Anna Luise Kirkengen

anlui-k@online.no

Eline Thornquist

I løpet av de siste månedene har den norske offentlighet fulgt med i og vært opptatt av to strafferettslige prosesser: Den såkalte Christoffer-saken $(1,2)$ og det som i pressen er blitt omtalt som Alvdal-saken $(3,4)$. Det første straffeforhold gjaldt langvarig mishandling av en gutt med døden til følge. Det andre forholdet omfattet seksuelt misbruk av flere barn.

Til tross for betydelige forskjeller hadde disse rettssakene noe til felles - begge var en fortsettelse av tidligere strafferettslig vurderte forhold der foreldre og/eller steforeldre har sittet på tiltalebenken anklaget for overgrep som hovedsakelig var blitt utført i barnas hjem. Nå var det mødrene som var siktet, og begge ble dømt. Christoffers mor ble dømt for «passiv medvirkning», fordi hun unnlot å beskytte sønnen mot en voldelig stefar som for et par år siden ble dømt for legemsbeskadigelse med døden til følge. Den andre moren er tidligere blitt dømt fordi hun misbrukte sine barn seksuelt, nå også for misbruk av en datter som ikke var klager i den første rettslige vurderingen. I denne saken - Alvdal-saken - var barn ofre for foreldres, steforeldres og naboers overgrep.

Sakene har det til felles at de ikke har dreid seg om enkeltstående hendelser og handlinger, men om systematiske overgrep over tid.

Mange spørsmål reiser seg i forlengelsen av disse rettssakene. Mediene har primært rettet søkelyset mot strafferettslige forhold og mot problemer som springer ut av den sterke beskyttelse av privatlivets fred i vårt samfunn. Mange har ment at straffeutmålingen i begge disse sakene har vært for mild, og mange har uttrykt bekymring når det gjelder håndteringen av voldssaker mot barn generelt. For øvrig virker det som om «alle» er enige om at rettssakene har fungert som vekkere og at de har styrket barns rettssikkerhet. Hovedbudskapet i mediene er dette: Vi er alle ansvarlige for å si ifra når vi får kjennskap til vold, mishandling og overgrep.

Vårt anliggende er et annet enn medienes, selv om problemområdene berører hverandre. Vi vil drøfte og problematisere diagnosers funksjoner i vid forstand (5). Derigjennom stiller vi spørsmål ved bruk og misbruk av diagnostikk generelt og spesielt av diagnosene som ble omtalt $i$ disse sakene. Begge ofrene i de to rettssakene hadde vært gjennom omfattende medisinsk utredning: Christoffer hadde fått diagnosen $\mathrm{AD} / \mathrm{HD}$ (attention deficit/hyperactive disorder), den unge kvinnen hadde som barn fått diagnosen Aspergers syndrom. Selv om diagnosene i seg selv har vært omtalt i begge disse sakene, har det så vidt oss bekjent ikke vært drøftet hvilke virkninger de kan ha hatt og hvordan de særlig angår leger og annet helsepersonell.

\section{Diagnostikk - flere funksjoner}

Diagnoser har som kjent flere funksjoner noen tilsiktede, andre utilsiktede. Deres primære funksjon er å gi retningslinjer for (be)handling. Men det er makt knyttet til å definere et helseproblem, det dreier seg om retten til å skape bestemte virkelighetsbilder og bestemme hvilke problemer som hører inn under medisinens og helsevesenets ansvarsområde. Forestillingen om diagnoser som objektive og udiskutable kategorier og diagnostikk som nøytral kartlegging har solid fotfeste i mange kretser både $\mathrm{i}$ og utenfor helsevesenet.

Likeledes er det en utbredt tendens til at medisinske oppfatninger overordnes alle andre oppfatninger av «virkeligheten». Med referanse blant annet til bruken av AD/ HD skriver profesjonssosiologen Andrew Abbott: «Man baserer seg på den forestilling at subjektive oppfatninger er erstattet av objektive definisjoner, som om disse ikke omfattet subjektive vurderinger» (6). Dermed flyttes lidelsen «fra den sosiale til den kliniske arena» (7).

I et tilbakeblikk virker det som den medisinske navngivingen, selve diagnostiseringen, i begge de to aktuelle tilfellene fungerte som effektive blikkavledere. Som følge av at bestemte observerbare væremåter og verbalt formidlede erfaringer og plager var gitt symptomstatus, ble barna kategorisert som «syke», altså som preget av bestemte patologiske tilstander, og ikke som «skadet» av noe som var blitt påført eller påtvunget dem av andre. Det er tankevekkende - og verdt å dvele ved - at diagnosene og grunnlaget for å stille dem ikke ble trukket inn i rettssakene. Væremåter og helseplager hos begge barna ble «lest» inn i en medisinsk forståelsesramme og tillagt symptombetydning. Diagnosene fikk således en slags forklaringsverdi som preget omgivelsenes blikk. Fordi man antok at barna led av en sykdom, så man ikke at de var blitt skadelidende av overgrep og mishandling.

Diagnosene AD/HD og Aspergers syndrom stilles på grunnlag av symptomer og oppførsel som kan skyldes ulike forhold (8). Faren ved alle diagnoser er å bruke dem til å forklare ulike - iblant alle - aspekter ved en persons være- eller levemåte (5). Medisinens status, koblet med dens sannhetspretensjoner, kan legge sterke føringer på omgivelsenes blikk og bidra til at både leg og lærd underkjenner egne erfaringer, observasjoner og vurderinger. Måten å begrepsfeste plager på styrer dessuten pasientenes egen selvforståelse.

Konsekvensen kan være at både pasientene selv og de som møter dem ikke tør stole på egne erfaringer eller vurderinger så sant disse strider mot medisinske «sannheter». Diagnosene forfører i en viss forstand alle, slik at de ser gjennom det som kan kalles medisinske briller, eller med det idéhistorikeren Michel Foucault identifiserte og beskrev som «det medisinske blikket» (9).

\section{Faglig forsømmelse}

I den internasjonale forskningslitteraturen er det for lengst påpekt at det er en faglig forsømmelse når helsepersonell enten ikke tenker på eller ikke aktivt etterspør krenkelseserfaring, eller når de ignorerer tegn på problemer og avmakt som pasienten formidler mer eller mindre tydelig verbalt og/ eller kroppslig (10-12). Begge deler skjer, og de bidrar med lik andel til at slike erfaringer ikke inngår i den medisinskfaglige vurdering av en aktuell sykdom.

Studiene viser ikke bare at krenkelser og sykdom åpenbart henger sammen, selv om 


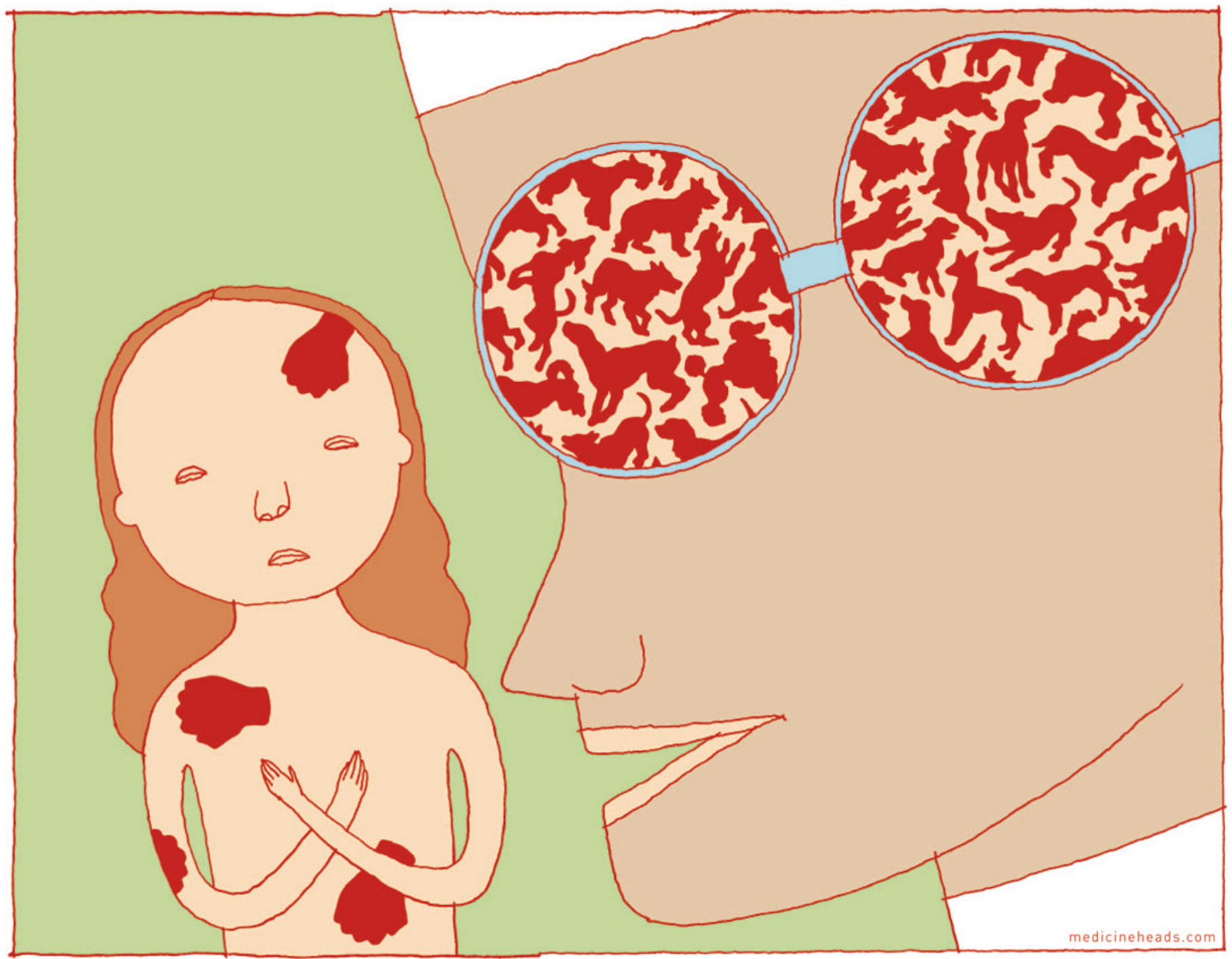

Illustrasjon (c) Trond Nordahl

det medisinsk sett ennå er uklart hvordan $(13,14)$. De dokumenterer også hvor liten vekt helseprofesjonene tillegger traumatisk erfaring som element i menneskers helse og at leger stort sett ikke innhenter informasjon som handler om traumer, bortsett fra ulykkesskader (15).

Denne patologifremmende dynamikken er blitt omtalt og karakterisert som «the interaction between the cycle of domestic violence and the cycle of professional neglect» (15). Helsearbeidernes manglende interesse for og kunnskap om krenkelser som foregår i private rom og bak lukkede dører, bidrar til at slike krenkelser kan fortsette. Dermed føres de videre fra generasjon til generasjon og kan resultere i ulike typer sykelighet.

Den dokumenterte sykelighet som følger av krenkelser omfatter kreft, hjerte- og karsykdommer, hjerneslag, diabetes type 2 , infeksjoner og kroniske systemiske inflammasjoner samt en rekke mentale lidelser, slik WHO-rapporten Violence and health tydeliggjør (16). Det betyr at faglig ignorering bidrar til den omtalte sirkelen på flere nivåer, det vil si i forskning, undervisning og praksis. Slik ignorering er ikke forenlig med helseprofesjonenes oppdrag og faglige selvforståelse.

\section{Kropp og sykdom - avpersonifisert}

Et kjerneproblem i den biomedisinske kunnskapsproduksjonen handler om medisinens menneskesyn og kroppsforståelse. Biomedisinsk kunnskap er reduksjonistisk i sitt vesen og basert på en avpersonifisert kropp, en kropp løsrevet fra menneskelig erfaring og mening - noe som resulterer i et tilsvarende snevert kunnskapssyn (17-19).

En fyllestgjørende kunnskap om helse og sykdom krever imidlertid at man tar høyde for at mennesker eksisterer i verden som kroppslige erfarende vesener, og at all form for menneskelig erfaring har betydning og kan få konsekvenser for helse og sykdomsutvikling. Mennesker er historiske vesener - erfaringer kan ikke tilintetgjøres, alle erfaringer blir med oss videre i livet, men de kan kanaliseres og ytre seg på mange og ulike måter $(5,11-14)$.

Med et syn på kroppen som ignorerer den menneskelige erfarings- og meningsverden står man alltid i fare for å tolke symptomer, avvikende oppførsel og patologiske funn som tegn på sykdom i den enkeltes kropp som løsrevet fra samspillet med andre mennesker og uten å inkludere personens livssammenheng $(20,21)$. Men siden dette kropps- og menneskesynet er basert på en abstrahert forestilling som er lite dekkende for mennesker slik de lever livet, søker man også «løsninger» som er inadekvate og som 
kan tilsløre sykdomsskapende relasjoner og miljøer og forverre plager og lidelser (22).

\section{Medikalisering}

Enkelte tilstander er spesielt utfordrende å omgås. Det gjelder ikke minst problemer som befinner seg i grenselandet mellom det som tradisjonelt defineres som somatikk og psykiatri, eksempelvis AD/HD og Aspergers syndrom. Som diagnoser er de omstridt, hvilket kan avleses av at begge for tiden er under revisjon i overgangen fra DSM-IV til DSM-5.

Siden diagnosene AD/HD og Aspergers syndrom brukes stadig oftere, er det nærliggende å spørre om grunnlaget for dette og hvilke virkninger det har i vid forstand. Det er viktig å se Christoffer-saken og Alvdalsaken i sammenheng med vår tids medikalisering, der stadig flere problemer defineres som uttrykk for sykdom. I forlengelse av disse sakene trengs det følgelig en debatt om hva som styrer våre blikk, hva som er grunnlaget for å sette diagnoser og hva diagnosene kan (mis)brukes til.

\section{Anna Luise Kirkengen (f. 1946)}

er spesialist i allmennmedisin og professor I ved Allmennmedisinsk forskningsenhet ved Norges teknisk-naturvitenskapelige universitet og ved Institutt for samfunnsmedisin, Universitetet i Troms $\varnothing$

Forfatter har fylt ut ICMJE-skjemaet og oppgir ingen interessekonflikter.

\section{Eline Thornquist (f. 1947)}

er professor i fysioterapi ved Institutt for ergoterapi, fysioterapi og radiografi ved Høgskolen i Bergen.

Forfatter har fylt ut ICMJE-skjemaet og oppgir ingen interessekonflikter.

\section{Litteratur}

1. Christoffer-saken. http://no.wikipedia.org/wiki/ Christoffer-saken (30.5.2013).

2. Christoffer-saken. www.vg.no/nyheter/spesial. php?id=8397 (30.5.2013)

3. Alvdal-saken - samleside oppdateres. www. familiestiftelsen.no/node/15225 (30.5.2013).

4. Alvdal-saken. www.dagbladet.no/tag/alvdal-saken (30.5.2013)

5. Thornquist E. Kommunikasjon: Teoretiske perspektiver på praksis i helsetjenesten. 2. utg. Oslo: Gyldendal Akademisk, 2009

6. Abbott A. The system of professions. Chicago: The University of Chicago Press, 1988.

7. Summerfield D. The invention of posttraumatic stress disorder (PTSD) and the social usefulness of psychiatric categories. BMJ 2001; 322: 95-8.

8. Diagnostic and Statistical Manual of Mental Disor ders. Fourth Edition. Washington D.C.: American Psychiatric Association, 2005.

9. Foucault M. The birth of the clinic: an archeology of medical perception. New York: Vintage Books, 1975

10. Becker-Blease KA, Freyd JJ. Research participants telling the truth about their lives: the ethics of asking and not asking about abuse. Am Psychol 2006; 61: 218-26

11. Felitti VJ, Anda RF. The relationship of adverse childhood experiences to adult medical disease, psychiatric disorders and sexual behavior: implications for healthcare. I: Lanius RA, Vermetten E, Pain $C$, red. The impact of early life trauma on health and disease. The hidden epidemic. Cambridge: Cambridge University Press, 2010.

12. Read J, Hammersley P, Rudegeair T. Why, when and how to ask about childhood abuse. Adv Psychiatr Treat 2007; 13: 101-10.

13. American Academy of Pediatrics. Policy statement: Early childhood adversity. Toxic stress, and the role of the pediatrician: translating developmental science into lifelong health. Pediatrics 2012. doi: 10.1542/peds.2011-2662

14. American College of Obstetricians and Gynecologists. ACOG Committee Opinion No. 518: Intimate partner violence. Obstet Gynecol 2012; 119: 412-7.

15. Krugman RD, Cohn F. Time to end health profes sional neglect of cycle of violence. Lancet 2001; 358: 434.

16. Krug EG, Mercy JA, Dahlberg LL et al. The world report on violence and health. Lancet 2002; 360 : 1083-8.

17. Cassell EJ. The person in medicine. Int J Integr Care 2010; 10 (Suppl): e019

18. Leder D. red. The body in medical thought and practice. Dordrecht: Kluwer Academic Publishers, 1992

19. Gordon DR. Tenacious assumptions in Western medicine. I: Lock M, Gordon DR, red. Biomedicine examined. Dordrecht: Kluwer Academic Publishers, 1988.

20. Kirkengen AL, Thornquist E. The lived body as a medical topic: an argument for an ethically informed epistemology. J Eval Clin Pract 2012; 18 1095-101.

21. Thornquist E. Vitenskapsfilosofi og vitenskapsteori for helsefag. Bergen: Fagbokforlaget, 2003.

22. Kirkengen AL. Inscribed bodies. Dordrecht Kluwer Academic Publishers, 2001.

Mottatt 19.4. 2013, første revisjon innsendt 6.5. 2013, godkjent 13.5. 2013. Medisinsk redaktør Sigurd Høye.

ar Engelsk oversettelse på www.tidsskriftet.no

Publisert først på nett 